PRZEGLĄD BIBLIOTECZNY 2020 z. 1

PL ISSN 0033-202X

JACEK DROGOSZ

Ośrodek Przetwarzania Informacji PIB

e-mail: Jacek.Drogosz@opi.org.pl

\title{
DOROBEK PIŚMIENNICZY PRACOWNIKÓW NAUKOWYCH Z DYSCYPLINY BIBLIOLOGIA I INFORMATOLOGIA W ŚWIETLE OCENY PARAMETRYCZNEJ DZIAŁALNOŚCI NAUKO- WEJ POLSKICH JEDNOSTEK NAUKOWYCH Z ROKU 2017
}

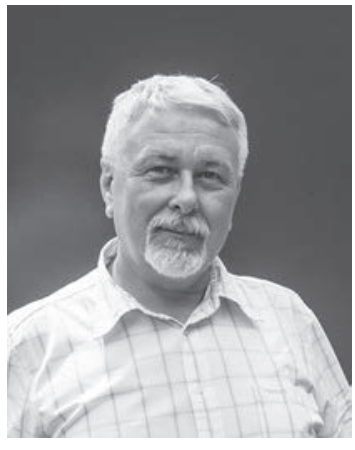

Jest pracownikiem Działu Zasobów Informacyjnych Ośrodka Przetwarzania Informacji - Państwowego Instytutu Badawczego, gdzie zajmuje się pracami związanymi z procesem ewaluacji nauki. W latach 1994-2016 pracował w bibliotekach naukowych i publicznych. W pracy bibliotekarskiej zajmował się głównie wdrażaniem systemów informatycznych i digitalizacją. Pomysłodawca i współrealizator projektu digitalizacji „Polskiej Bibliografii Lekarskiej 1901-1939”. Autor publikacji m.in. w czasopismach „Forum Bibliotek Medycznych”, „Biuletyn Głównej Biblioteki Lekarskiej”, "Guliwer”, „Bibliotekarz”, „Family Medicine \& Primary Care Review”.

SŁOWA KLUCZOWE: Bibliologia i informatologia. Czasopisma naukowe. Ewaluacja nauki. Konferencje naukowe. Wydawnictwa naukowe.

ABSTRAKT: Teza/cel artykułu - Artykuł prezentuje informacje o polskim dorobku piśmienniczym pracowników naukowych z dyscypliny bibliologia i informatologia za lata 2013-2016. Celem badania jest wskazanie najpopularniejszych w dyscyplinie czasopism, wydawnictw i konferencji naukowych oraz określenie ich znaczenia w kolejnym procesie ewaluacji (2021). Pozwala to na wyciągnięcie wstępnych wniosków dotyczących realizacji 
polityki naukowej w zakresie bibliologii i informatologii. Metody badań - Materiał opracowany został na podstawie danych $\mathrm{z}$ ankiet jednostek, które oceniane były w procesie parametryzacji w 2017 r. Stosując metody analityczne wyodrębniono informacje o dorobku piśmienniczym pracowników reprezentujących dyscyplinę. Dane o czasopismach, wydawnictwach i konferencjach zostały uszeregowane metodą rankingowania. Wzięto pod uwagę różnorodne zapisy danych przez sprawozdających, które to zapisy zostały ujednolicone na potrzeby artykułu. Wyniki/wnioski - Z analizy wynika, że znaczna część najcenniejszego dorobku piśmienniczego w badanej dyscyplinie straci znaczenie w ewaluacji. Zwrócono uwagę na konieczność dostosowania się do nowych zasad ewaluacji w celu podniesienia znaczenia dorobku naukowego. Wskazano, że reprezentatywność analizowanych publikacji w dorobku naukowym badanej dyscypliny jest tylko częściowa.

\section{WSTĘP}

Ewaluacja działalności naukowej odbywa się w Polsce co cztery lata. W 2017 r. przeprowadzono ocenę dorobku naukowego z lat 2013-2016. Ocena poszczególnych osiągnięć dokonana została przez zespoły ewaluacji powołane przez przewodniczącego Komitetu Ewaluacji Jednostek Naukowych (KEJN). Po zakończeniu szczegółowej oceny osiągnięć przewodniczący KEJN wystąpił do ministra nauki i szkolnictwa wyższego z wnioskiem o przyznanie jednostkom kategorii naukowej wynikającej $\mathrm{z}$ oceny dorobku naukowego. Minister przyznał kategorie naukowe w drodze decyzji (Skoczeń, 2018).

\section{ZASADY EWALUACJI 2017}

Podstawą prawną oceny parametrycznej przeprowadzonej w 2017 r. były:

- ustawa z dnia 30 kwietnia 2010 r. o zasadach finansowania nauki;

- rozporządzenie Ministra Nauki i Szkolnictwa Wyższego z dnia 12 grudnia 2016 r. w sprawie przyznawania kategorii naukowej jednostkom naukowym i uczelniom, w których zgodnie $\mathrm{z}$ ich statutami nie wyodrębniono podstawowych jednostek organizacyjnych;

- rozporządzenie Ministra Nauki i Szkolnictwa Wyższego z dnia 29 czerwca 2015 r. w sprawie Systemu Informacji o Nauce.

Ewaluacja przeprowadzona w 2017 r. objęła 993 jednostki naukowe, które w terminie złożyły ankietę jednostki zawierającą szczegóły osiągnięć naukowych z lat 2013-2016. Osiagnnięcia oceniane były w zakresie czterech kryteriów:

- kryterium I obejmujące osiągnięcia naukowe i twórcze jednostki;

- kryterium II obejmujące potencjał naukowy jednostki;

- kryterium III obejmujące praktyczne efekty działalności naukowej i artystycznej jednostki; 
- kryterium IV obejmujące pozostałe efekty działalności naukowej i artystycznej. Odróżniało się ono od pozostałych tym, że w jego zakresie dokonywana była ocena ekspercka.

Analiza obejmuje jedynie osiągnięcia z kryterium I, konkretnie dorobek piśmienniczy:

1. Publikacje naukowe:

a) zamieszczone $\mathrm{w}$ czasopismach naukowych $\mathrm{z}$ części A wykazu czasopism naukowych Ministra Nauki i Szkolnictwa Wyższego;

b) zamieszczone w czasopismach naukowych z części B wykazu;

c) zamieszczone $\mathrm{w}$ czasopismach naukowych z części $C$ wykazu;

d) zamieszczone $\mathrm{w}$ zagranicznych czasopismach naukowych spoza wykazu;

e) zamieszczone $\mathrm{w}$ materiałach $\mathrm{z}$ konferencji międzynarodowych, uwzględnionych w bazie Web of Sciences (WoS) (MNiSW, 2017).

2. Monografie naukowe i rozdziały w monografiach naukowych.

$\mathrm{W}$ analizie nie zostały uwzględnione pozostałe osiągnięcia z kryterium I. W przypadku grupy nauk humanistyczno-społecznych (obejmującej m.in. jednostki naukowe specjalistów w dyscyplinie bibliologia i informatologia) są to przede wszystkim osiągnięcia w działalności innowacyjnej (patenty, wdrożenia wynalazków, prawa ochronne i autorskie) (Skoczeń, 2016).

\section{CEL BADANIA}

Przeprowadzona analiza ma na celu:

- stworzenie rankingu czasopism, które były najpopularniejsze wśród pracowników naukowych z dyscypliny bibliologia i informatologia - jako miejsce publikacji wyników własnych badań;

- ocena ilościowa monografii naukowych i rozdziałów opublikowanych przez pracowników naukowych z tejże dyscypliny;

- stworzenie rankingu wydawnictw, które opublikowały te monografie;

- wskazanie najbardziej prestiżowych konferencji naukowych, na których pracownicy $\mathrm{z}$ badanej dyscypliny zaprezentowali swe prace;

- określenie przewidywanej oceny wartości dorobku piśmienniczego wg zasad kolejnej ewaluacji.

\section{BADANE JEDNOSTKI NAUKOWE I ICH CHARAKTERYSTYKA}

W badaniu zostały wzięte pod uwagę jednostki naukowe, w których zatrudnione i wliczone do liczby $\mathrm{N}$ były osoby przypisane do dyscypliny bibliologia i informatologia. Przypisanie to zostało wykazane $\mathrm{w}$ ankietach jednostek złożonych na potrzeby oceny parametrycznej w 2017 r. 
Zgodnie z rozporządzeniem Ministra Nauki i Szkolnictwa Wyższego z dnia 8 sierpnia 2011 r. w sprawie obszarów wiedzy, dziedzin nauki i sztuki oraz dyscyplin naukowych i artystycznych, dyscyplina ta należała do dziedziny nauk humanistycznych w obszarze nauk humanistycznych.

Badanie objęło dorobek piśmienniczy pracowników naukowych 29 jednostek zatrudniających łącznie 194 pracowników z badanej dyscypliny. W poszczególnych jednostkach pracowało ich od 1 do 39.

Jednostki zatrudniające najwięcej bibliologów i informatologów to:

1. Uniwersytet Warszawski; Wydział Historyczny (39).

2. Uniwersytet Warszawski; Wydział Dziennikarstwa, Informacji i Bibliologii (35).

3. Uniwersytet Śląski w Katowicach; Wydział Filologiczny (31).

4. Uniwersytet Mikołaja Kopernika w Toruniu; Wydział Nauk Historycznych (21).

5. Uniwersytet Wrocławski; Wydział Filologiczny (18).

6. Uniwersytet Jagielloński w Krakowie; Wydział Zarządzania i Komunikacji Społecznej (16).

7. Uniwersytet Łódzki; Wydział Filologiczny (13).

8. Uniwersytet Pedagogiczny im. Komisji Edukacji Narodowej w Krakowie; Wydział Filologiczny (9).

9. Uniwersytet Jana Kochanowskiego w Kielcach; Wydział Humanistyczny (8).

10. Uniwersytet Kazimierza Wielkiego w Bydgoszczy; Wydział Administracji i Nauk Społecznych (8).

11. Uniwersytet Marii Curie-Skłodowskiej w Lublinie; Wydział Humanistyczny (4).

12. Uniwersytet im. Adama Mickiewicza w Poznaniu; Wydział Neofilologii (3).

13. Muzeum Sztuki Współczesnej w Krakowie MOCAK (3).

Po dwóch specjalistów z tej dyscypliny zatrudniały:

- Uniwersytet Pedagogiczny im. Komisji Edukacji Narodowej w Krakowie; Wydział Pedagogiczny;

- Uniwersytet Szczeciński; Wydział Filologiczny;

- Uniwersytet w Białymstoku; Wydział Filologiczny;

- Instytut Logistyki i Magazynowania.

Po jednym specjaliście:

- Uniwersytet Gdański; Wydział Filologiczny;

- Instytut Ceramiki i Materiałów Budowlanych;

- Uniwersytet Warmińsko-Mazurski w Olsztynie; Wydział Humanistyczny;

- Instytut Chemii i Techniki Jądrowej;

- Uniwersytet Zielonogórski; Wydział Pedagogiki, Psychologii i Socjologii; 
- Wyższa Szkoła Bankowa w Toruniu; Wydział Finansów i Zarządzania w Toruniu;

- Uniwersytet im. Adama Mickiewicza w Poznaniu; Wydział Pedagogiczno-Artystyczny w Kaliszu;

- Instytut Transportu Samochodowego;

- Uniwersytet Jana Kochanowskiego w Kielcach; Filia w Piotrkowie Trybunalskim; Wydział Filologiczno-Historyczny;

- Akademia im. Jakuba z Paradyża; Wydział Humanistyczny;

- Międzynarodowa Wyższa Szkoła Logistyki i Transportu we Wrocławiu; Wydział Logistyki i Transportu;

- Uniwersytet Warszawski; Centrum Europejskie Uniwersytetu Warszawskiego.

Wyżej wymienione jednostki wykazały łącznie 228 specjalistów z omawianej dyscypliny, jednakże należy zaznaczyć, że:

1. Dwie czołowe jednostki wykazały w ankietach za okres sprawozdawczy 32 te same osoby, co jest związane z utworzeniem w 2016 r. Wydziału Dziennikarstwa, Informacji i Bibliologii. Tyle właśnie osób przeszło z Wydziału Historycznego do wydziału nowo utworzonego (wg danych ankiety).

2. Jedna osoba z Wydziału Historycznego UW została wykazana również w ankiecie Centrum Europejskiego UW.

3. Jedna osoba z Wydziału Nauk Historycznych UMK w Toruniu znalazła się również w ankiecie Wydziału Finansów i Zarządzania Wyższej Szkoły Bankowej w Toruniu.

Faktyczna ilość bibliologów i informatologów we wszystkich jednostkach wynosi zatem 194. Ich procentowy udział w poszczególnych jednostkach przestawiał się następująco.

Tylko w pięciu jednostkach pracownicy ci stanowili powyżej 10\% składu osobowego:

1. Uniwersytet Warszawski; Wydział Dziennikarstwa, Informacji i Bibliologii (41\%).

2. Muzeum Sztuki Współczesnej w Krakowie MOCAK (18\%).

3. Uniwersytet Mikołaja Kopernika w Toruniu; Wydział Nauk Historycznych $(15 \%)$.

4. Uniwersytet Kazimierza Wielkiego w Bydgoszczy; Wydział Administracji i Nauk Społecznych (15\%).

5. Uniwersytet Warszawski; Wydział Historyczny (13\%).

Na koniec okresu sprawozdawczego Wydział Dziennikarstwa, Informacji i Bibliologii Uniwersytetu Warszawskiego pozostaje w kraju niekwestionowanym liderem w reprezentowaniu dyscypliny, jaką jest bibliologia i informatologia. Zatrudniał on największą liczbę przedstawicieli dyscypliny. Stanowili oni nieporównywalnie najwyższy odsetek (41\%) wśród wszystkich jednostek, poza tym - jest to jedyna jednostka z grupy uczest- 
niczących w parametryzacji mająca w nazwie zadeklarowaną dyscyplinę bibliologia i informatologia.

$\mathrm{W}$ pięciu jednostkach pracownicy dyscypliny stanowili od 5 do $7 \%$, w jedenastu - od 1 do $4 \%$, w ośmiu - poniżej 1\%. Czyli w większości badanych jednostek stanowili zaledwie margines.

\section{DOROBEK PIŚMIENNICZY BADANYCH PRACOWNIKÓW}

Spośród 194 pracowników reprezentujących dyscyplinę, dorobkiem piśmienniczym wykazało się 148 osób (76\%).

Ogółem jednostki naukowe zadeklarowały do oceny dorobek piśmienniczy osób z badanej grupy w postaci:

- 433 artykułów ze 109 czasopism naukowych,

- 116 monografii sprawozdanych w całości,

- 557 rozdziałów z 217 monografii (18 monografii zostało sprawozdanych - w zależności od jednostki - zarówno całościowo, jak i częściowo $-\mathrm{w}$ formie rozdziałów),

- czterech publikacji w materiałach konferencyjnych będących pokłosiem czterech konferencji naukowych.

$\mathrm{Na}$ jednego pracownika w badanej dyscyplinie w okresie czteroletnim przypadło więc 5,7 publikacji. Jeśli wziąć pod uwagę wyłącznie pracowników aktywnie publikujących, na osobę przypadało prawie 7,5 publikacji.

Najpopularniejsze wśród polskich pracowników naukowych z badanej dyscypliny czasopisma naukowe jako miejsce publikacji własnych badań przedstawione zostały $\mathrm{w}$ Tabeli 1 . Formy zapisu danych czasopism podane niekiedy przez sprawozdających w różnorodny sposób zostały ujednolicone.

Czasopisma naukowe zostały ujęte całościowo, bez podziału na poszczególne części wykazu Ministra, jednak w każdym przypadku wykaz został oznaczony. Podano również punktację z wykazu czteroletniego, liczbę artykułów opublikowanych przez pracowników z dyscypliny (podstawa szeregowania w rankingu), a także profil czasopisma w oparciu o dyscypliny z najnowszego rozporządzenia. Oznaczono również, czy czasopismo znalazło się w wykazie z 2019 r. oraz punktację na potrzeby parametryzacji 2021 (MNiSW, 2019d).

Do stworzenia rankingu wzięte zostały pod uwagę materiały konferencyjne opublikowane w czasopismach, choć te do celów ewaluacji należało sprawozdać w odrębnej grupie. 
Tabela 1

Ranking najpopularniejszych czasopism dla dyscypliny bibliologia i informatologia

\begin{tabular}{|c|c|c|c|c|c|c|c|c|c|}
\hline 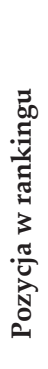 & $\begin{array}{c}\text { Tytuł } \\
\text { czasopisma }\end{array}$ & ISSN & Profil & 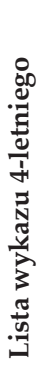 & 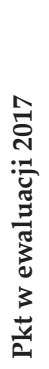 & 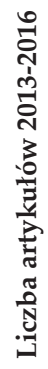 & 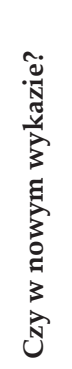 & 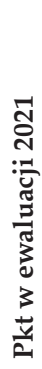 & 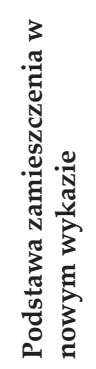 \\
\hline & 1 & 2 & 3 & 4 & 5 & 6 & 7 & 8 & 9 \\
\hline 1 & $\begin{array}{l}\text { Przegląd } \\
\text { Biblioteczny }\end{array}$ & $0033-202 X$ & $\begin{array}{l}\text { nauki o komunikacji } \\
\text { społecznej i mediach }\end{array}$ & B & 9 & 52 & TAK & 20 & $\mathrm{WCN}$ \\
\hline 2 & $\begin{array}{l}\text { Toruńskie } \\
\text { Studia } \\
\text { Bibliologiczne }\end{array}$ & $2080-1807$ & $\begin{array}{l}\text { nauki o komunikacji } \\
\text { społecznej i mediach }\end{array}$ & B & 6 & 39 & TAK & 20 & ERIH+ \\
\hline 3 & $\begin{array}{l}\text { Acta } \\
\text { Universitatis } \\
\text { Lodziensis. } \\
\text { Folia Librorum }\end{array}$ & $0860-7435$ & $\begin{array}{l}\text { nauki o komunikacji } \\
\text { społecznej i mediach }\end{array}$ & B & 4 & 32 & NIE & 5 & - \\
\hline 4 & $\begin{array}{l}\text { Bibliotheca } \\
\text { Nostra. Śląski } \\
\text { Kwartalnik } \\
\text { Naukowy }\end{array}$ & $1734-6576$ & $\begin{array}{l}\text { nauki o komunikacji } \\
\text { społecznej i mediach }\end{array}$ & B & 9 & 29 & NIE & 5 & - \\
\hline 5 & $\begin{array}{l}\text { Rocznik } \\
\text { Historii Prasy } \\
\text { Polskiej }\end{array}$ & $1509-1074$ & $\begin{array}{l}\text { historia, } \\
\text { literaturoznawstwo, } \\
\text { nauki o komunikacji } \\
\text { społecznej i mediach }\end{array}$ & B & 11 & 22 & TAK & 40 & ERIH+ \\
\hline 6 & $\begin{array}{l}\text { Zagadnienia } \\
\text { Informacji } \\
\text { Naukowej }\end{array}$ & 0324-8194 & $\begin{array}{l}\text { nauki o komunikacji } \\
\text { społecznej i mediach }\end{array}$ & B & 8 & 21 & TAK & 20 & $\mathrm{WCN}$ \\
\hline 7 & $\begin{array}{l}\text { PTINT } \\
\text { Praktyka } \\
\text { i Teoria } \\
\text { Informacji } \\
\text { Naukowej } \\
\text { i Technicznej }\end{array}$ & $1230-5529$ & $\begin{array}{l}\text { nauki o komunikacji } \\
\text { społecznej i mediach }\end{array}$ & B & 8 & 18 & NIE & 5 & - \\
\hline 8 & $\begin{array}{l}\text { Forum } \\
\text { Bibliotek } \\
\text { Medycznych }\end{array}$ & $1899-5829$ & $\begin{array}{l}\text { nauki o komunikacji } \\
\text { społecznej i mediach }\end{array}$ & B & 7 & 13 & NIE & 5 & - \\
\hline 9 & $\begin{array}{l}\text { Nowa } \\
\text { Biblioteka }\end{array}$ & 1505-4195 & $\begin{array}{l}\text { nauki o komunikacji } \\
\text { społecznej i mediach }\end{array}$ & B & 4 & 12 & NIE & 5 & - \\
\hline
\end{tabular}




\begin{tabular}{|c|c|c|c|c|c|c|c|c|c|}
\hline & 1 & 2 & 3 & 4 & 5 & 6 & 7 & 8 & 9 \\
\hline 10 & \begin{tabular}{|l|} 
Annales \\
Universitatis \\
Paedagogicae \\
Cracoviensis. \\
Studia ad \\
Bibliothecarum \\
Scientiam \\
Pertinentia
\end{tabular} & 2081-1861 & $\begin{array}{l}\text { nauki o komunikacji } \\
\text { społecznej i mediach }\end{array}$ & B & 7 & 11 & TAK & 20 & ERIH+ \\
\hline 11 & $\begin{array}{l}\text { Zeszyty } \\
\text { Kaliskiego } \\
\text { Towarzystwa } \\
\text { Przyjaciół } \\
\text { Nauk }\end{array}$ & $1426-6547$ & $\begin{array}{l}\text { historia, nauki } \\
\text { o kulturze i religii, } \\
\text { nauki o sztuce, } \\
\text { nauki o komunikacji } \\
\text { społecznej i mediach, } \\
\text { pedagogika }\end{array}$ & B & 6 & 10 & NIE & 5 & - \\
\hline $12-13$ & $\begin{array}{l}\text { Roczniki } \\
\text { Biblioteczne }\end{array}$ & $0080-3626$ & $\begin{array}{l}\text { nauki o komunikacji } \\
\text { społecznej i mediach }\end{array}$ & B & 7 & 8 & NIE & 5 & - \\
\hline $12-13$ & $\begin{array}{l}\text { Studia } \\
\text { o Książce } \\
\text { i Informacji }\end{array}$ & 0524-4471 & $\begin{array}{l}\text { nauki o komunikacji } \\
\text { społecznej i mediach }\end{array}$ & B & 7 & 8 & NIE & 5 & - \\
\hline $14-15$ & \begin{tabular}{|l} 
Sztuka \\
Edycji. Studia \\
Tekstologiczne \\
i Edytorskie
\end{tabular} & $2084-7963$ & $\begin{array}{l}\text { historia, } \\
\text { literaturoznawstwo }\end{array}$ & B & 5 & 7 & TAK & 20 & ERIH+ \\
\hline $14-15$ & $\begin{array}{l}\text { Zeszyty } \\
\text { Prasoznawcze }\end{array}$ & 0555-0025 & $\begin{array}{l}\text { nauki o komunikacji } \\
\text { społecznej i mediach }\end{array}$ & B & 14 & 7 & TAK & 20 & ERIH+ \\
\hline $16-17$ & $\begin{array}{l}\text { Folia } \\
\text { Toruniensia }\end{array}$ & $1641-3792$ & $\begin{array}{l}\text { nauki o komunikacji } \\
\text { społecznej i mediach }\end{array}$ & B & 6 & 6 & TAK & 20 & ERIH+ \\
\hline $16-17$ & $\begin{array}{l}\text { Rocznik } \\
\text { Bibliologiczno- } \\
\text { Prasoznawczy }\end{array}$ & $2080-4938$ & $\begin{array}{l}\text { nauki o komunikacji } \\
\text { społecznej i mediach }\end{array}$ & B & 7 & 6 & NIE & 5 & - \\
\hline 18 & $\begin{array}{l}\text { Zarządzanie } \\
\text { Biblioteką }\end{array}$ & 2081-1004 & $\begin{array}{l}\text { nauki o komunikacji } \\
\text { społecznej i mediach }\end{array}$ & B & 5 & 5 & NIE & 5 & - \\
\hline $19-20$ & $\begin{array}{l}\text { Góry - } \\
\text { Literatura - } \\
\text { Kultura }\end{array}$ & 2084-4107 & $\begin{array}{l}\text { literaturoznawstwo, } \\
\text { nauki o kulturze } \\
\text { i religii, nauki } \\
\text { o sztuce, architektura } \\
\text { i urbanistyka }\end{array}$ & B & 7 & 4 & NIE & 5 & - \\
\hline $19-20$ & $\begin{array}{l}\text { Qualitative } \\
\text { and } \\
\text { Quantitative } \\
\text { Methods in } \\
\text { Libraries }\end{array}$ & 2241-1925 & $\begin{array}{l}\text { nauki o komunikacji } \\
\text { społecznej i mediach }\end{array}$ & - & 5 & 4 & TAK & 20 & $\begin{array}{l}\text { Web of } \\
\text { Sciences }\end{array}$ \\
\hline
\end{tabular}

Źródło: oprac. własne.

Spośród 20 najpopularniejszych czasopism zawierających powyżej trzech sprawozdanych artykułów, niemal wszystkie (19) to czasopisma 
polskie, odnotowane w wykazie 4-letnim na liście B z punktacją od 4 do 14 . Spośród nich tylko osiem znalazło się w nowym wykazie czasopism: dwa z tytułu programu Wsparcia dla Czasopism Naukowych (najbardziej znane w branży bibliotekarskiej naukowe czasopisma: „Przegląd Biblioteczny” i „Zagadnienia Informacji Naukowej”) z wartością po 20 pkt. sześć natomiast zostało dodanych z listy ERIH+, z reguły z wartością 20 pkt. zaś jedno („Rocznik Historii Prasy Polskiej”) z wartością 40 pkt.

Zdecydowana większość z nich była ściśle związana bibliologią i informatologią. Na podstawie najnowszych przepisów, przy zmniejszeniu liczby dyscyplin naukowych, utworzono nową (nauki o komunikacji społecznej i mediach), łączącą bibliologię i informatologię z dyscyplinami pokrewnymi. Większość czasopism ujętych w powyższej tabeli zakwalifikowana została wyłącznie do tej właśnie dyscypliny. Z kolei dwa spośród nich to czasopisma interdyscyplinarne, kolejne dwa zostały odmiennie sklasyfikowane.

Ewenementem jest czasopismo, które zajęło w rankingu ex aequo pozycję 19-20 - "Qualitative and Quantitative Methods in Libraries". Jest to czasopismo wydawane w Grecji, które nie znalazło się w wykazie 4-letnim. (Za publikację w takim czasopiśmie przyznawano 5 pkt.) Do najnowszego wykazu, gdzie zastosowano ostre kryteria doboru, trafiło ono jednak z racji posiadania wskaźników bibliometrycznych w bazie WoS Przyznano mu najniższą w wykazie wartość 20 pkt.

Warto również wspomnieć, że na dalszych miejscach $\mathrm{w}$ rankingu, wśród czasopism, gdzie naukowcy z badanej grupy zamieścili po 2-3 artykuły, znalazły się:

- czasopisma z bazy WoS („e-mentor"; "Journal of Information Science"),

- czasopisma z bazy Scopus („Kwartalnik Historii Nauki i Techniki”; "Journal of Information Science"),

- czasopisma z listy ERIH+ („Przegląd Historyczno-Oświatowy”; "Klio"; „Roczniki Naukowe Wyższej Szkoły Bankowej w Toruniu”),

- czasopisma z programu Wsparcie dla Czasopism Naukowych („,Bibliotekarz Podlaski”; "Studia Medioznawcze”; "Archiwa Biblioteki i Muzea Kościelne”; ,Przegląd Historyczny").

Najwyżej punktowane spośród nich wg nowego wykazu jest czasopismo "Journal of Information Science" odnotowywane w obydwu najbardziej prestiżowych bazach, któremu przyznano w wykazie 100 pkt.

Celem wprowadzenia nowych przepisów jest zmotywowanie pracowników naukowych do prezentowania swoich prac w czasopismach o wyższej renomie - na poziomie światowym. Z kolei wydawcy czasopism chcący otrzymać wysoką punktację powinni starać się odnotowywać je w bazach WoS, Scopus lub ERIH+, czy choćby brać udział w konkursach ministerialnych w celu wpisania swojego czasopisma do wykazu. 
Nikt zapewne przy ocenie nie zakwestionuje naukowego charakteru niżej punktowanych dotychczas czasopism z listy B, więc publikowane w nich artykuły będą mogły otrzymać po 5 punktów. Należy jednak pamiętać, że brak publikacji danego pracownika w czasopiśmie pochodzącym z wykazu skutkował będzie dla podmiotu naukowego zmniejszeniem dozwolonej liczby sprawozdanych prac, co z kolei obniży końcowy wynik. Zasady te zostały opublikowane $\mathrm{w}$ najnowszym rozporządzeniu dotyczącym ewaluacji (MNiSW, 2019a).

Kolejna grupa osiągnięć w zakresie dorobku piśmienniczego to monografie naukowe oraz zamieszczone w nich rozdziały. Monografie sprawozdawane całościowo lub częściowo (poprzez pojedyncze rozdziały) $\mathrm{z}$ reguły klasyfikowały się $\mathrm{w}$ dyscyplinie bibliologia i informatologia.

W dotychczas przeprowadzanej ewaluacji nie miało znaczenia, $\mathrm{z}$ jakiego wydawnictwa pochodziła monografia. W nowej ewaluacji znacząca liczba punktów zostanie przyznana tylko w przypadku monografii pochodzących od wydawców odnotowanych w ministerialnym wykazie. Warto więc przeanalizować monografie pod tym kątem. Zostały tu wzięte pod uwage jedynie te sprawozdane całościowo, ale gdyby uwzględnić tu również monografie sprawozdane tylko w postaci pojedynczych rozdziałów, kolejność w rankingu byłaby zbliżona. Przy poszczególnych wydawnictwach podano, czy zostały one ujęte w nowym wykazie opracowanym na potrzeby przyszłej ewaluacji oraz liczba punktów dla monografii i rozdziału za publikację. (MNiSW, 2019c).

Tabela 2 przedstawia ranking wydawnictw, w których zostały opublikowane monografie autorstwa pracowników z badanej dyscypliny. Podobnie jak w przypadku czasopism, ujednolicono zapisy podane przez sprawozdających w różnorodny sposób.

Pracownicy naukowi wydają swoje monografie najczęściej w wydawnictwach prowadzonych przez rodzime uczelnie. Należy jednak zwrócić uwagę na pierwsze miejsce $\mathrm{w}$ rankingu, na którym uplasowało się Wydawnictwo Stowarzyszenia Bibliotekarzy Polskich. Publikacje SBP są znane i cenione przez pracowników bibliotek (nie tylko uczelnianych), innych instytucji kultury czy ośrodków informacji. Ma to niewątpliwy wpływ na poczytność $\mathrm{w}$ środowisku zawodowym treści naukowych powstałych $\mathrm{w}$ ramach prac uczelni. Upowszechnienie dorobku naukowego w gospodarce i społeczeństwie to jedno z kryteriów, które będzie mieć duże znaczenie w kolejnej ewaluacji.

Dwie spośród monografii z badanej grupy pochodzą z wydawnictw ujętych w wykazie ministerialnym na poziomie II - „Palgrave Macmillan UK” oraz „Peter Lang GmbH”. Zasadnicza punktacja dla tych wydawców to 200 pkt za monografię i 50 za rozdział. Warto zaznaczyć, że w dziedzinie nauk humanistycznych punktacja ta będzie podwyższona o 50\% i będzie wynosić 300 pkt za monografię i 75 pkt za rozdział (MNiSW, 2019b, s. 44-45). 
Tabela 2

Ranking najpopularniejszych wydawnictw dla dyscypliny bibliologia i informatologia.

\begin{tabular}{|c|c|c|c|c|c|}
\hline $\begin{array}{l}\text { Miejsce } \\
\mathbf{w} \\
\text { rankingu }\end{array}$ & Wydawca & 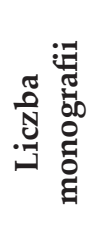 & 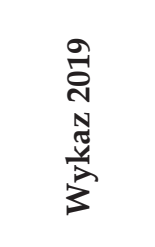 & 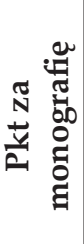 & 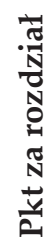 \\
\hline 1 & $\begin{array}{l}\text { Wydawnictwo Stowarzyszenia } \\
\text { Bibliotekarzy Polskich }\end{array}$ & 15 & Poziom I & 80 & 20 \\
\hline 2 & $\begin{array}{l}\text { Wydawnictwo Naukowe } \\
\text { Uniwersytetu Mikołaja Kopernika }\end{array}$ & 14 & Poziom I & 80 & 20 \\
\hline 3 & $\begin{array}{l}\text { Wydawnictwo Uniwersytetu } \\
\text { Śląskiego }\end{array}$ & 10 & Poziom I & 80 & 20 \\
\hline 4 & $\begin{array}{l}\text { Wydawnictwo Uniwersytetu Jana } \\
\text { Kochanowskiego }\end{array}$ & 7 & Poziom I & 80 & 20 \\
\hline 5 & $\begin{array}{l}\text { Wydawnictwo Uniwersytetu } \\
\text { Łódzkiego }\end{array}$ & 6 & Poziom I & 80 & 20 \\
\hline 6 & $\begin{array}{l}\text { Wydawnictwo Uniwersytetu } \\
\text { Kazimierza Wielkiego w } \\
\text { Bydgoszczy }\end{array}$ & 5 & Poziom I & 80 & 20 \\
\hline 7 & $\begin{array}{l}\text { Wydawnictwo Uniwersytetu } \\
\text { Wrocławskiego }\end{array}$ & 4 & Poziom I & 80 & 20 \\
\hline $8-13$ & Księgarnia Akademicka & 3 & Poziom I & 80 & 20 \\
\hline $8-13$ & Oficyna Wydawnicza ASPRA-JR & 3 & - & 20 & 5 \\
\hline $8-13$ & $\begin{array}{l}\text { Wydawnictwo Naukowe } \\
\text { Uniwersytetu Adama } \\
\text { Mickiewicza }\end{array}$ & 3 & Poziom I & 80 & 20 \\
\hline $8-13$ & $\begin{array}{l}\text { Wydawnictwo Naukowe } \\
\text { Uniwersytetu Pedagogicznego } \\
\text { w Krakowie }\end{array}$ & 3 & Poziom I & 80 & 20 \\
\hline $8-13$ & $\begin{array}{l}\text { Wydawnictwo Uniwersytetu } \\
\text { Jagiellońskiego }\end{array}$ & 3 & Poziom I & 80 & 20 \\
\hline $8-13$ & $\begin{array}{l}\text { Wyższa Szkoła Bankowa } \\
\text { w Toruniu }\end{array}$ & 3 & - & 20 & 5 \\
\hline
\end{tabular}

Źródło: oprac. własne.

Dorobek zaprezentowany $\mathrm{w}$ ewaluacji jako materiały konferencyjne podlegał ostrzejszym kryteriom oceny. Do tej grupy (względnie wysoko punktowanej) mogły zostać zaliczone tylko te prace, które zostały odnoto- 
wane w bazie WoS. To pozwala na wyodrębnienie z całego szeregu konferencji tych najbardziej prestiżowych.

W dorobku pracowników naukowych z dyscypliny bibliologia i informatologia zostały sprawozdane jedynie cztery kwalifikowane materiały konferencyjne z czterech różnych konferencji. Były to dwa artykuły z czasopism oraz dwa rozdziały w monografiach. Konferencje, z których sprawozdano materiały to:

- 4th International Conference of the CLEF Initiative "Information access evaluation: multilinguality, multimodality, and visualization". Hiszpania - Valencia, 23-26.09.2013;

- 9th International Conference on Natural Language Processing. Polska - Warszawa, 17-19.09.2014;

- 15th International Society of Scientometrics and Informetrics Conference. Turcja - Istanbul, 29.06 - 03.07.2015;

- Federated Conference on Computer Science and Information Systems 2015, Polska - Łódź, 13-16.09.2015.

Żadna z wymienionych konferencji nie znalazła się w najnowszym ministerialnym wykazie. Nowy wykaz zawiera jedynie konferencje uwzględnione $\mathrm{w}$ bazie informatycznych konferencji naukowych CORE (The Computing Research and Education Association of Australasia), a więc dotyczące nauk informatycznych. Warto jednak zaznaczyć, że część konferencji ujętych w wykazie ma charakter interdyscyplinarny. Niektóre z nich dotyczą informacji naukowej, a więc stanowią przedmiot zainteresowania bibliologów i informatologów. Stwarza to w tej grupie naukowej szansę na wysoko punktowane publikacje (MNiSW, 2019b, s. 30-31).

\section{WNIOSKI}

$\mathrm{Na}$ podstawie zebranego materiału z oceny parametrycznej istnieje możliwość zaprezentowania szeregu wykazów piśmiennictwa związanych z bibliologią i informatologia, które łącznie stanowiłyby materiał do bibliografii przekraczającej znacznie objętość pojedynczego artykułu:

- wykaz opublikowanych artykułów (bibliografię zawartości czasopism),

- wykaz wszystkich czasopism, w których publikowali pracownicy naukowi,

- wykaz monografii z dyscypliny bibliologia i informatologia,

- wykaz opublikowanych rozdziałów w monografiach,

- bibliografię prac naukowych wypracowanych przez pracowników naukowych z tej dyscypliny bez względu na formę wydawniczą.

Ze sprawozdanego materiału można również sporządzić zestawienia dotyczące innych osiągnięć naukowych niż tylko piśmiennicze (wykazy projektów, patentów, wdrożeń). 
Przy sporządzaniu analizy zaprezentowanej w niniejszym tekście wychodzimy z założenia, że w ankietach jednostki zawarte są wszystkie najważniejsze osiągnięcia polskiej nauki. Należy jednak zwrócić uwagę na pewne aspekty, które ograniczają kompletność dorobku naukowego w ocenianym materiale:

1. Wybitne publikacje naukowe tworzone przez specjalistów mogą powstawać w ramach prac instytucji, których nie ma na liście jednostek naukowych. W bibliotekarskich czasopismach branżowych często ukazują się wartościowe i odkrywcze teksty autorstwa bibliotekarzy będących pracownikami instytucji niepodlegających ewaluacji.

2. Twórcy mogli afiliować swoje publikacje $\mathrm{w}$ innych instytucjach niż macierzyste, o których było wiadomo, że poddadzą się ocenie. Nie zawsze jednak z tego korzystali. Stąd cenne prace bibliologów i informatologów mogły zostać przypisane na konto jednostek naukowych (lub innych instytucji), które nie uczestniczyły w parametryzacji. Nie zostały więc wykazane $\mathrm{w}$ tym procesie.

3. Jednostki naukowe nie miały obowiązku poddawania się procesowi ewaluacji. Ocena parametryczna prowadzona była na ich wniosek. Publikacje pracowników jednostek, które nie zgłosiły swojego dorobku do oceny nie były brane pod uwagę. Mogły więc zostać pominięte w zaliczeniu do całkowitego krajowego dorobku naukowego.

4. Jednostki naukowe często nie sprawozdawały w ankietach całości dorobku piśmienniczego, a jedynie najwyżej punktowane publikacje. Spowodowane to było ograniczeniami ilościowymi wynikającymi z zapisów rozporządzenia dotyczącego ewaluacji. Osiągnięcia nisko punktowane podawane były tylko przez te jednostki, które miały w dorobku stosunkowo niewiele prac bądź były one niższej jakości. Natomiast w przypadku dużej liczby wysoko punktowanych publikacji istniało duże prawdopodobieństwo odrzucenia $\mathrm{w}$ procesie oceny tych mniej wartościowych, więc ich zamieszczanie $\mathrm{w}$ ankiecie byłoby dla wielu jednostek stratą czasu (Kulczycki, 2017; Kulczycki, 2015).

Dlatego też ocena ogółu osiągnięć na podstawie danych z ewaluacji jako całego krajowego dorobku byłaby w dużym stopniu niemiarodajna. Tak wygląda sytuacja, kiedy popatrzymy na problem od strony teoretycznej. Patrząc od strony praktycznej, zdajemy sobie sprawę, że pracownicy uwzględnieni w artykule to właśnie ci, którzy w pewien sposób kształtują polską politykę naukową $\mathrm{w}$ dyscyplinie bibliologia i informatologia.

W chwili obecnej (sierpień 2019) gotowe są już nowe przepisy dotyczące ewaluacji nauki, przewidzianej na $2021 \mathrm{r}$. Z jednej strony, odchodzi się od oceniania samych jednostek w ramach podmiotu (uczelni bądź instytutu), a oceniać się będzie dorobek pracowników poszczególnych dyscyplin, zdefiniowanych nowym rozporządzeniem. Pozwoli to wspólnie ocenić dorobek wszystkich pracowników całego podmiotu w obrębie 
danej dyscypliny - bez względu na przynależność do konkretnej jednostki. Z drugiej zaś strony, wymagane będzie do przeprowadzenia oceny kadrowe minimum (12 pracowników z danej dyscypliny w podmiocie), co z kolei stanowi ograniczenie - dorobek części pracowników zostałby pominięty. Jednakże zakres tematyczny podstawowych dyscyplin będzie rozszerzony. Bibliologia i informatologia będą oceniane $\mathrm{w}$ ramach dyscypliny nauka o komunikacji społecznej i mediach, co ułatwi zebranie minimum. Ale może też dojść do sytuacji, kiedy uzyskanie minimum w jednostce związane będzie ze zmianą przez pracowników deklarowanej dyscypliny (MNiSW, 2019b, s. 15-16).

Dorobek piśmienniczy zgłaszany do ewaluacji zostanie poddany większym ograniczeniom ilościowym. Pozwoli to na wyodrębnienie najcenniejszych publikacji z danej dyscypliny, ale ograniczy rolę ewaluacji jako źródła wiedzy o całości produkcji piśmienniczej (Kulczycki 2018; Skoczeń 2019).

Niemniej każda informacja o dorobku piśmienniczym pozwala na wyciągnięcie wniosków o poziomie prac naukowych w poszczególnych dyscyplinach, co z kolei może pomóc $\mathrm{w}$ planowaniu i realizacji polityki naukowej w polskich uczelniach i instytutach.

Analiza materiału sprawozdanego przez jednostki naukowe $\mathrm{w}$ ankietach do ewaluacji pozwala nie tylko na ich ocenę, ale również na pewne przewidywania odnośnie efektów kolejnej parametryzacji. Dzięki opracowaniu zasad ewaluacji z odpowiednim wyprzedzeniem, instytucje naukowe (już nie jednostki, ale podmioty) będą się mogły odpowiednio przygotować i wdrożyć u siebie właściwą politykę naukową dotyczącą m.in. prowadzenia badań i prezentacji ich wyników we właściwy sposób.

Autorzy prac naukowych szczególną uwagę powinni zwrócić na zawartość opublikowanych w 2019 r. wykazów wydawnictw i czasopism naukowych. Natomiast wydawcy monografii i czasopism na bieżąco powinni śledzić przepisy dotyczące zasad tworzenia tych wykazów, jeśli chcą zachować prestiż swych publikacji.

\section{BIBLIOGRAFIA}

Kulczycki, Emanuel (2017). Punktoza jako strategia w grze parametrycznej w Polsce. Nauka i Szkolnictwo Wyższe, z. 1 (49), s. 63-78.

Kulczycki, Emanuel (2018). Ewaluacja jednostek naukowych 2017-2020 [online]. PAN naukowiec; [dostęp: 11.08.2019]. Dostępny w WWW: <https://pannaukowiec.wordpress.com/2018/04/19/ewaluacja-jednostek-naukowych-2017-2020>.

Kulczycki, Emanuel; Drabek, Aneta; Rozkosz, Ewa (2015). Publikacje a zgłoszenia ewaluacyjne, czyli zniekształcony obraz nauki w Polsce. Nauka, z. 3, s. 35-58.

MNiSW (2017). Komunikat w sprawie wykazu czasopism naukowych wraz z liczbą punktów przyznanych za publikacje naukowe w tych czasopismach, 
ustalony na podstawie wykazów ogłoszonych w latach 2013-2016 [online]. Ministerstwo Nauki i Szkolnictwa Wyższego; [dostęp: 11.08.2019]. Dostępny w WWW: <http://www.bip.nauka.gov.pl/wykaz-czasopism-naukowych/ komunikat-w-sprawie-wykazu-czasopism-naukowych-wraz-z-liczba-punktow-przyznanych-za-publikacje-naukowe-w-tych-czasopismach-ustalony-na -podstawie-wykazow-ogloszonych-w-latach- 2013-2016.html>.

MNiSW (2019a). Jak oceniane będą jednostki naukowe? Prezentujemy rozporządzenie ws. ewaluacji [online]. KDN Konstytucja Dla Nauki; [dostęp: 11.08.2019]. Dostępny w WWW: <https://konstytucjadlanauki.gov.pl/jak-oceniane-beda-jednostki-naukowe-prezentujemy-rozporzadzenie-ws-ewaluacji>. MNiSW (2019b). Ewaluacja jakości działalności naukowej - przewodnik [online]. KDN Konstytucja Dla Nauki; [dostęp: 20.11.2019]. Dostępny w WWW: $<$ https://konstytucjadlanauki.gov.pl/content/uploads/2019/03/ewaluacja-jakosci-dzialalnosci-naukowej-przewodnik20190305.pdf>.

MNiSW (2019c). Pierwsza wersja nowego wykazu wydawnictw już jest. Większość pozycji to wydawnictwa polskie [online]. KDN Konstytucja Dla Nauki; [dostęp: 18.08.2019]. Dostępny w WWW: <https://konstytucjadlanauki.gov.pl/ pierwsza-wersja-nowego-wykazu-wydawnictw-juz-jest-wiekszosc-pozycji-to -wydawnictwa-polskie>.

MNiSW (2019d). Komunikat Ministra Nauki i Szkolnictwa Wyższego z dnia 31 lipca 2019 r. w sprawie wykazu czasopism naukowych i recenzowanych materiałów z konferencji międzynarodowych wraz z przypisaną liczbą punktów [online]. Ministerstwo Nauki i Szkolnictwa Wyższego; [dostęp: 18.08.2019]. Dostępny w WWW: <http://www.bip.nauka.gov.pl/akty-prawne-mnisw/ komunikat-ministra-nauki-i-szkolnictwa-wyzszego-z-dnia-31-lipca-2019-r -w-sprawie-wykazu-czasopism-naukowych-i-recenzowanych-materialow-z -konferencji-miedzynarodowych-wraz-z-przypisana-liczba-punktow.html>.

Skoczeń Błażej (2016). Ocena parametryczna jednostek naukowych 2017 [online]. Kolegium Prorektorów ds. Nauki i Rozwoju publicznych wyższych szkół technicznych; [dostęp: 21.05.2019]. Dostępny w WWW: <http://www.kpnir.pwr. wroc.pl/prezentacje/Ocena_parametryczna_jednostek_naukowych_2017_ prof.B.Skoczen.pdf>.

Skoczeń, Błażej (2019). Nowa dynamika ewaluacji i kategoryzacji dyscyplin, Forum Akademickie [online], nr 5 [dostęp: 10.06.2019]. Dostępny w WWW: $<$ https://prenumeruj.forumakademickie.pl/fa/2019/05/nowa-dynamika-ewaluacji-i-kategoryzacji-dyscyplin>.

Skoczeń, B.; Fijałkowski, S.; Jackowski, S.; Marcinkowska, M.; Pilc, A.; Zabel, M. (2018). Kategoryzacja jednostek naukowych 2017, Forum Akademickie [online], nr 2 [dostęp: 21.05.2019]. Dostępny w WWW: <https://prenumeruj.forumakademickie.pl/fa/2018/02/kategoryzacja -jednostek-naukowych-2017>.

Artykut w wersji poprawionej wptyną do Redakcji 21 listopada 2019 r. 
JACEK DROGOSZ

National Information Processing Institute

e-mail: Jacek.Drogosz@opi.org.pl

\section{PUBLICATIONS OF ACADEMIC STAFF IN THE FIELD OF BOOK STUDIES AND INFORMATION STUDIES USED TO EVALUATE THE SCIENTIFIC ACTIVITY OF POLISH RESEARCH UNITS IN 2017}

KEYWORDS: Evaluation of science. Book studies and information studies. Academic journals. Academic publications. Academic conferences.

ABSTRACT: The author discusses publications of Polish academic staff in the field of book studies and information studies that appeared between 2013 and 2016. Thesis/Objective - The author aims to indicate the most popular academic journals, publications and conferences in the field under discussion and define their significance for the incoming evaluation period (2021). That may allow for some preliminary conclusions on how the academic policy has been implemented in the field of book studies and information studies. Research methods - The article is based on the data collected from the surveys answered by the units evaluated in 2017. The analysis enabled the author to extract information on publications of the academic staff affiliated to the field being discussed. Data on journals, publications and conferences were ordered with ranking method. Data recorded in varying formats were harmonized for the article purposes. Results/Conclusions - The analysis shows that a significant number of most valuable publications in the field under research will become unimportant in the incoming evaluation process. The author emphasizes that the academic staff have to adjust to new evaluation rules in order to enhance the value of their publications. He stresses that the analyzed publications are only partially representative for the overall output of the discipline under discussion. 